\title{
Terminology of fruit set and fruit drop of sour cherry cultivars
}

\author{
Davarynejad, G.H. ${ }^{1}$, Nyéki, J. ${ }^{2}$, Tornyai, J. ${ }^{2}$, Szabó Z. ${ }^{2} \&$ Soltész M. ${ }^{2}$ \\ ${ }^{1}$ Department of Horticulture, Ferdowsi University of Mashhad Iran \\ ${ }^{2}$ University of Debrecen, Institute for Research and Development, Hungary
}

\begin{abstract}
Summary: Fruit set and fruit drop rates of 9 sour cherry cultivars ('Érdi bőtermő', 'Debreceni bőtermő', 'Kántorjánosi', 'Újfehértói fürtös', 'Éva', 'Petri' 'Oblocsinszka', 'Pandy 279' and 'Csengődi') of eight years-old trees grown in Újfehértó, located in the Eastern north part of Hungary which grafted on Prunns mahaleb have been studied. Significant differences have been found in fruit set among cultivars. The average percentage of fruit set was $18.3 \%$, which the 'Oblocsinszka' by $32.6 \%$ the highest fruit set, while 'Debreceni bőtermő' is very similar to 'Pandy 279' showed lowest (12\%) fruit set. Seasonal changes of fruit set and drop shows that there are four abscission peaks. The first fruit abortion wave appears during second week after pollination Thereafter, the second and third dropping period was found during the third and forth weeks after pollination. The forth abscission happened on the forth week after pollination. The highest fruit drop happened on 'Pandy279' (92.4\%) very similar to 'Éva' (90\%) while the lowest fruit drop observed in 'Oblocsinszka' (71.5\%)
\end{abstract}

Key words: 'Érdi bőtermő', 'Debreceni bőtermő', 'Kántorjánosi', 'Újfehértói fürtös', 'Éva', 'Petri' 'Oblocsinszka', 'Pándy 279' and 'Csengődi'.

\section{Introduction}

Yield is determined to a large extent by fruit set and fruit drop ratio. In sour cherry orchards adequate yield is anticipated if pollination and fertilization process to be adequate. The most important factors affected the fruit set and drop are: heat, drought and the rainy spring weather during the blooming period as well as the excessive hot, cool or windy weather impairing pollination, combination of pollen donors and pollinated cultivars, the rootstock, soil fertility and lack of nutrients mainly nitrogen and drought in the soil or water stress, agro-technical management, moreover, belated pruning, the appearance of diseases and pests all influence the fate of flowers and become ripe fruits (Looney, 1996; Kozma et al. 2003). The regular bearing cultivars have a unique property of self-thinning capacity by which they maintain fruit load year after year. Drop of flower and fruits is common problem in most of the fruit crops, fruits continue to drop at various stage of development (Davarynejad et al. 1993; Nyéki et al. 2003) explained that not always the fruit drop is unpleasant, but drop of fruits at the initial stages of fruit development seems to be necessary, since fruit drop at initial stage saves tree from exhaustion. They explained that in apple, fruit yield depends on the fruit set percentage and the amount of fruit drop. Flower drop on sour cherry can also be due to several plant pathology or pest problems (Holb et al., 2005; Holb \& Schnabel, 2005).

As generally mentioned, dry springs are causing severe fruit drop (Davarynejad et al. 2009). In sweet cherry and pear, the first phase was more important, in sour cherry and plum, the severity of the first and second fruit drop was nearly equal (Soltész, 1997). In sweet and sour cherry, the second period of fruit drop may ensue earlier than June, 6 weeks after bloom, whereas their third fruit drop finishes in June, which is called also "red drop", it means that the fruits dropped started to ripen (Nyéki, 1978). Gardner et al. (1952) found the dynamics of fruit drop is very similar in apple, pear and sweet cherry. In opinion of Thompson (1996) in sour and sweet cherry, the flowers shed within 1.5-2.5 weeks. Nyéki (1978) recognized a couple of causes being responsible for the cleaning fruit drop of sweet cherry, plum and sour cherry. In sour cherry, he analyzed the rate of flowers, which failed to be fertilized and of those, which started to grow fruit maintained. The hardening process slowed down, and then the fruits are shed 10-25 days (Soltész, 2003). He believes that in sour cherry, preharvest fruit drop is rare, only at excessively heavy fruit load. Preharvest drop is aggravated by the wind depending on the fruit species and variety (Roemer, 1968-70; Way, 1973; Gautier, 1974). The most exposed species are in diminishing order apple, pear, plum, peach and black currant, whereas cherry is less endangered (Stösser, 2002).

Bradbury (1929) and Thompson (1996) concluded that sour cherry cultivars are prone to fruit drop, especially the self-fertile ones. In the experiment, 'Montmorency' lost $64 \%$, 'Early Richmond' 70\% of the fruit load until harvest.

Out of the stone fruits, 'Pándy meggy' was the object of studies on fruit drop by Nyéki (1978) referring to other sour cherry varieties data were published by Bradbury (1929), as well. 
All variants of Pándy meggy proved to be selfincompatible, and mutually inter-incompatible. Nyéki \& Soltész (1996) called the attention to the fact that the self-incompatible Pándy meggy cannot be fertilised by several self-fertile cultivars ('Debreceni bőtermő'ö, 'Kántorjánosi', 'Újfehértói fürtös'), i.e. they are interincompatible.

High rates of fruit drop were observed by Nyéki (1978) in 'Pándy meggy-114' (99.7\%), 'Pándy meggy-10' (98.9\%). As for the dynamics of fruit drop, early and late types were distinguished; ,early" fruit drop was found in 'Ciganymeggy-7', 'Pándy meggy-10' and ,late” in 'Báró Josika', 'Schattenmorelle' as distinct varieties or clones. The sour cherry 'Érdi bőtermő' is especially remarkable by its system of auto regulation, which is expressed in the "yellow" drop, which means that when the fruit was grown to the size of 6-8 $\mathrm{mm}$ diameter, a fraction of the load got yellowish and dropped.

The objectives of the present studies were to determine, all the variability of fruit set depending on self- or alternatively open pollination in Hungarian sour cherry cultivars.

\section{Material and methods}

Study was conducted on nine sour cherry cultivars Érdi bőtermő, 'Debreceni bőtermő', Kántorjánosi, Újfehértói fürtös, Éva, 'Petri', 'Oblocsinszka', 'Pándy 279'and 'Csengődi' of eight years-old trees which grown in Újfehértó, located in the Eastern north part of Hungary were observed and determined. The orchard was planted in 1999 with the tree spacing of $4.00 * 3.50 \mathrm{~m}$. Trees were grafted on Prunnus mahleb seedling. Soil preparation, fertilization and pest control were according to local recommendations and need. Tree training was done according to commercial practices, with the general goal of a spindle-shaped canopy. Grass alleyways were used in the rows. Irrigation and fruit thinning were not used.

Open pollinated flowers were observed, equally, on 5-10 branches 1.5-2 meter above ground level of four different orientations and comprising 400-500 flowers per cultivars.

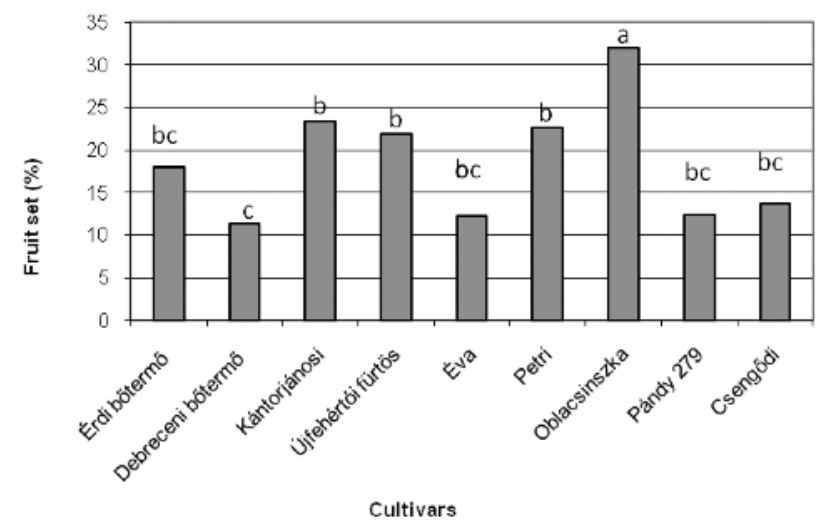

Figure 1. Final fruit set of Hungarian sour cherry cultivars (Újfehértó 2008)
Fruit set was registered and compared in all treatments and investigated on different orientation (N, E, S, and W). Number of flower and fruit set of a branch in 4 directions of trees was counted. The number of abscised fruits was recorded at second week after flowering till fruit ripening time in every week. The ratio of dropped fruits was expressed as a percentage of the total number of fruit set.

Statistical Analysis: Diameter data were analyzed as repeated measurement model using proc Mix from SAS software. Fruit set and drop fruit data was analyzed as completely randomized design using proc GLM from SAS software. Duncan's multiple range tests $(\alpha=0.05)$ were done using MSTATC program.

\section{Result and discussion}

\section{Fruit set}

Significant differences directly before to the harvest have been found in fruit set among cultivars, average percentage of fruit set following open pollination of all examined cultivars was $18.3 \%$, which the 'Oblacsinszka' by $32.6 \%$ the highest fruit set, while 'Debreceni bötermo"' is very similar to 'Pándy 279' showed lowest (12\%) fruit set which is agreed with the results of Nyéki (1989). He stated that fruit set of open pollinated Pándy meggy types is low and seasonally highly variable (Figure 1).

Fruit set and fruit shed varied substantially according to the direction of the trees. Direction of sunshine, wind direction, growing site as well as to the season, proves the susceptibility of sour cherry to micro ecological adversities. Figure $2 \mathrm{a}, \mathrm{b}$ and $\mathrm{c}$ shows fruit sets on open pollinated flowers of the sour cherry cultivars at different directions of trees. In the case of all examined cultivars the fruit set at each direction significantly differs except of 'Érdi bötermő' and 'Oblacsinszka' which the direction of the tree not affected significantly on fruit set. The trees on the east direction set more fruits in compare to the other directions. The eastern and western sides of the tree usually retain more fruits as compared to northern or southern side.

The lowest fruit set percentage belong to west direction of the trees. Most decisive is the influence of the direction on

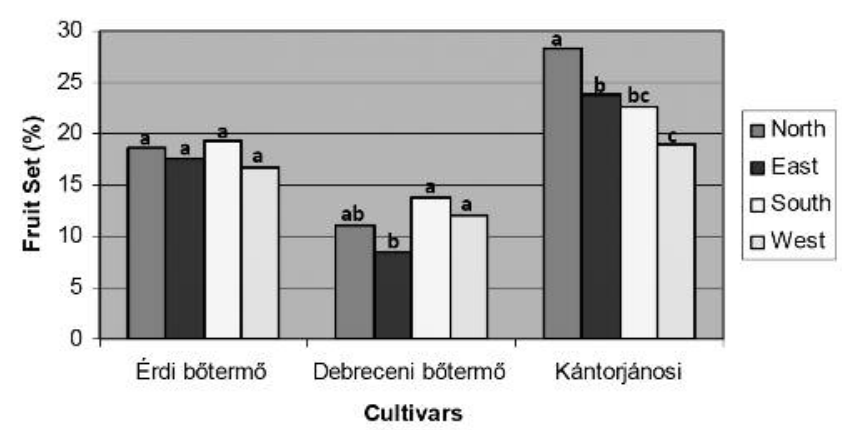

Figure $2 A$. Fruit set of sour cherry cultivars on different direction of the tree 


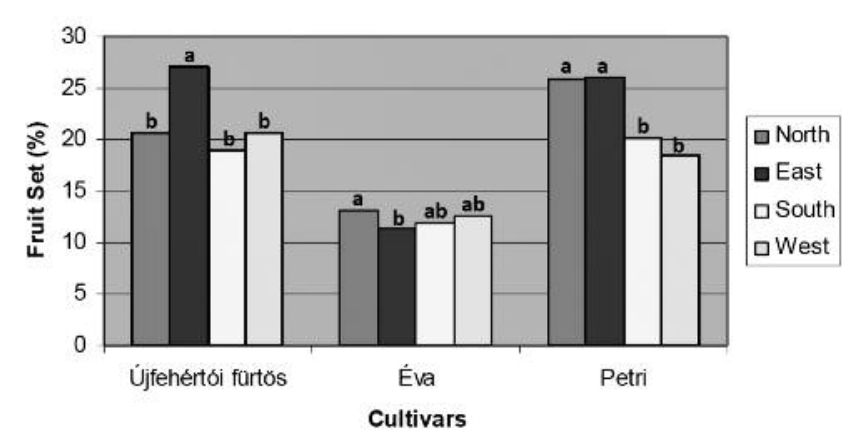

Figure 2 B. Fruit set of sour cherry cultivars on different direction of the tree

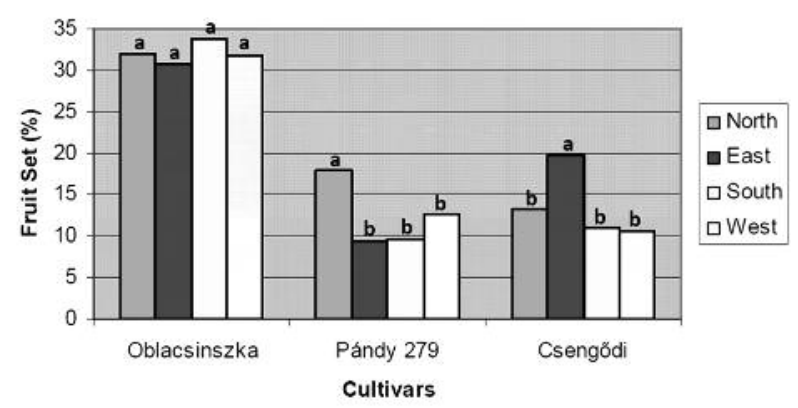

Figure 2C. Fruit set of sour cherry cultivars on different direction of the tree

fruit set during the blooming period. Just before harvest, average fruit set from open pollination of all cultivars in all directions was (18.3\%). which the highest fruit set measured on the north direction by $12.3 \%$, while the lowest fruit set obtained from west direction of the trees $(10.1 \%)$. The final fruit set of the cultivars varied in each direction, for example the lowest fruit set in the north belong to 'Debreceni bötermo"' by $5,2 \%$ and the highest amount belong to 'Oblacsinszka' by $22.2 \%$ of fruit set while at the east direction 'Újfehértói fürtös' by $16.6 \%$ produce highest amount of fruit and 'Petri' by $2,4 \%$ lowest. The 'Oblacsinszka' cultivar by $21.6 \%$ and $19.2 \%$ fruit set at the South and west respectively was the highest and 'Petri' by $3 \%$ at the south and 'Debreceni bőtermő' by $6 \%$ at the West were the lowest fruit set.

\section{Fruit drop}

There was no significant relationship between fruit set of open pollination and fruit drop of all examined cultivars. The lowest fruit drop from the trees belonged to 'Oblacsinszka' $(71.5 \%)$ If the first fruit set be equal to $100 \%$, the highest fruit drop happened on 'Pándy279' (92.4\%) very similar to 'Éva' (90\%). Seasonal changes of fruit set and drop of examined cultivars can be seen on Figure 3. There are four abscission peaks based on the average 9 sour cherry trees grafted on prunus mahaleb rootstock. The first fruit abortion wave appears during second week after pollination. In this time, large amount of dropping fruit is not characteristic. Thereafter, the second and third dropping period was found during the third and forth weeks after pollination. The forth abscission occurred on the forth week after pollination which also resulted in an amount of 1 percent of fruit. Fruit drop gradually diminishes on the other weeks. The 'Érdi bötermö' cultivar is especially remarkable by drop of yellowish red fruits (Figure 4). Soltész, (1997) believes that, in sour cherry and plum, the severity of the first and second fruit drop was nearly equal. High rates of fruit drop were observed by Nyéki (1978) in 'Pandy meggy 114' (99.7\%), 'Pandy meggy 10' $(98.9 \%)$. As for the dynamics of fruit drop, early and late types were distinguished; ,early" fruit drop was found in 'Ciganymeggy 7', 'Pandy meggy 10' and „late” in 'Báró Josika', 'Schattenmorelle' as distinct varieties or clones. In sweet and sour cherry, the second period of fruit drop may ensue earlier than June, 6 weeks after bloom, whereas their third fruit drop finishes in June, which is called also "red drop", it means that the fruits dropped started to ripen. Our results also are the same as results obtained by Nyéki (1978). He explained that in the case of 'Érdi bötermö' when the fruit was grown to the size of $6-8 \mathrm{~mm}$ diameter, a fraction of the load got yellowish and dropped.
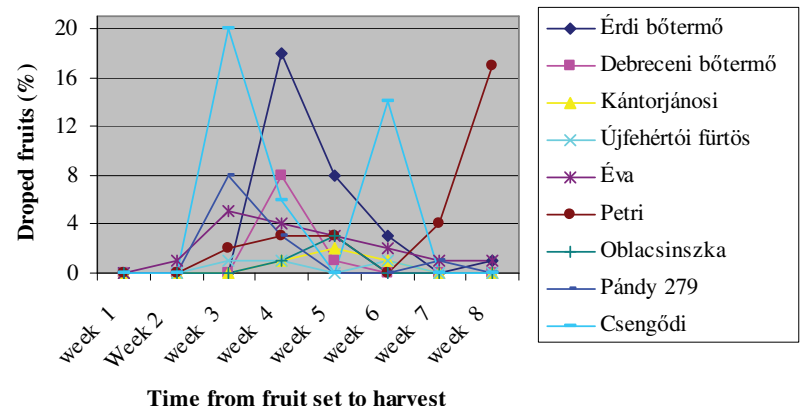

Figure 3. Seasonal changes of fruit drop of 9 sour cherry cultivars

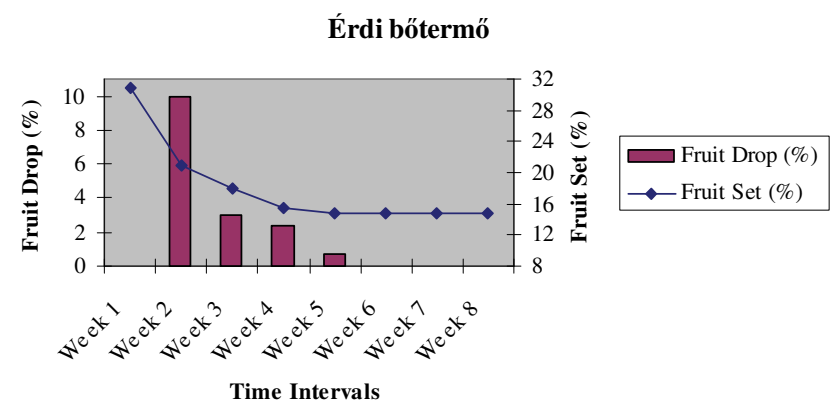

Figure 4. Seasonal changes of fruit set and drop of 9 sour cherry cultivars

Fruit abscission significantly varied among the direction of the trees. Most fruit abscission occurs at north direction. Least abscising fruits are also observed on the west direction of tree. The other two directions were mediocrity Figure $5 a$, $b$ and $c$. In the case of all examined cultivars the fruit shed at each direction differs except of 'Petri' and 'Oblacsinszka' which the direction of the tree not affected significantly on fruit shed. The trees on the east and north direction shed more fruits in compare to the other directions. The lowest fruit shed percentage belongs to west direction of the trees. The highest amounts of fruit shed belong to 'Pándy' at the east direction and the lowest fruit shed to 'Érdi bötermo"' at the north and west. (Figure $5 a, b$ and $c$ ). 


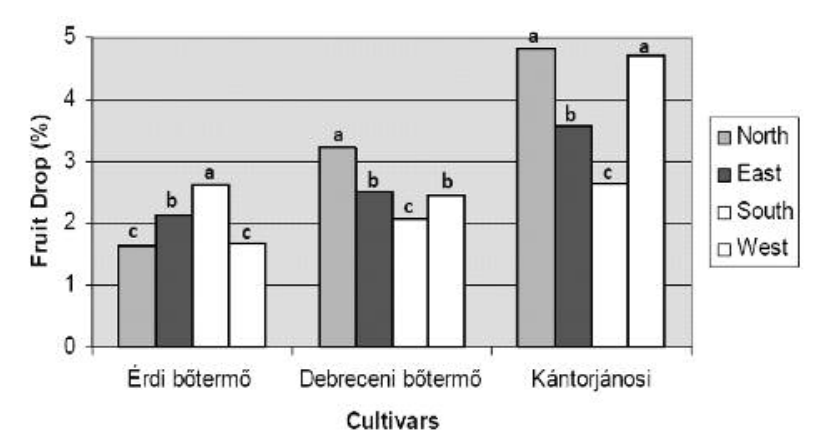

Figure 5A. Fruit drop of sour cherry cultivars on different direction of the tree

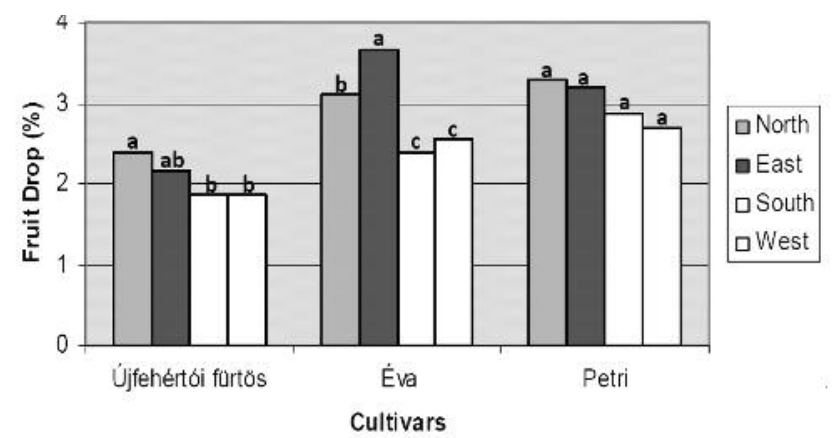

Figure 5B. Fruit drop of sour cherry cultivars on different direction of the tree

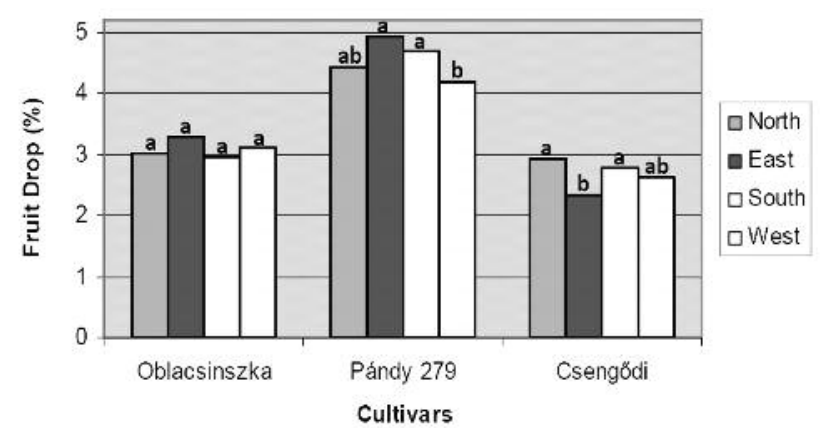

Figure 5C. Fruit drop of sour cherry cultivars on different direction of the tree

\section{References}

Bradbury, D. (1929): A comparative study of the developing and aborting fruits of Prunus cerasus. Amer. J. Bot., 16: 525-545.
Davarynejad, G.H., Nyéki, J. \& Szabóo, Z. 1993, Relationship between fertility and seed content in apple cultivars, Acta Agro. Hung., 42 (3-4): 365-375.

Gardner, V.R., Bradford, F.C. \& Hooker, H.D. Jr. (1952): The fundamentals of fruit production, New York

Gautier, M. (1974): Les variétés de pommiers. L'Arboriculture fruitiére, 21 (249): 21-27.

Holb, I.J. \& Schnabel, G. (2005): Comparison of fungicide treatments combined with sanitation practices on brown rot blossom blight incidence, phytotoxicity, and yield for organic sour cherry production Plant Disease, 89: 1164-1170.

Holb, I., Veisz J. \& Abonyi, F. (2005): A meggy és cseresznye komplex ökológiai növényvédelmi technológiája. (In: Holb, I. (szerk.) A gyümölcsösök és a szőlő ökológiai növényvédelme.) Mezőgazda Kiadó, Budapest, 168-171.

Kozma, P., Nyéki, J., Soltész, M. \& Szabó, Z. (ed.) (2003): Floral biology, pollination and fertilisation in temperate zone fruit species and grape. Akadémiai Kiadó, Budapest

Looney, N.E. (1996): Cherries: Crop physiology, production and uses. CABI Publishing, Wallingford, 223-241.

Nyéki, J. (1978): Meggyfajtak gyümölcshullása. A hullás mértéke és dinamikaja. Kertgazdaság, 10 (1): 31-38.

Nyéki, J. (1989): Csonthéjas gyümölcsűek viragzása és termékenyülése. Doktori értekezés. MTA, Budapest, pp. 288.

Nyéki J., Szabó T. \& Szabó Z. (2003): Flowering phenology and fertility of sour cherry cultivar selection in Hungary. Journal of Apicultural science, 47 (1): 51-58.

Nyéki, J. \& Soltész, M. (ed.) (1996): Floral biology of temperate zone fruit trees and small fruits. Akadémiai Kiadó, Budapest,pp. 377.

Roemer, K. (1968-70): Bericht über die Beobachtungen des Blühverganges und des Ansatzes bei einigen Apfelsorten des niederelbischen Obstanbaugebietes in der Zeit von 1964 bis 1968. Mitteil. Obstver. Jork 23: 222-239, 25: 209-215, 242-249, 299-309, 354-361.

Soltész, M. (1997): Terméskötődés és -ritkítás (In: Soltész, M. (ed.) (1997): Integrált gyümölcstermesztés.) Mezőgazda Kiadó, Budapest, pp. 309-331.

Soltész, M. (2003): A terméskötődés tényezői és mértéke (In: Papp, J. (ed.) (2003): Gyümölcstermesztési alapismeretek.) Mezőgazda Kiadó, Bp., 306-311.

Stöosser, R. (2002): Von der Blüte zur Frucht (In: Link, H. (ed.) (2002): Lucas' Anleitung zum Obstbau.) Eugen Ulmer GmbH Co., Stuttgart, 29-37.

Thompson, M. (1996): Flowering, pollination and fruit set (In: Webster, A.D. -Way, R.D. (1973): Summer and early fall apple varieties.) Fruit Var., J. 27 (1): 6-9. 